\title{
Africa: \\ Alternative Dispute Resolution in a Comparative Perspective
}

\author{
Nokukhanya NTULI
}

\begin{abstract}
In many African countries, attempts to address poor access to justice, have led to the promotion of Alternative Dispute Resolution (ADR), in the form of mediation, negotiation and arbitration. The popularisation and promotion of ADR is done using "international best practices and standards" developed in countries such as the USA, Australia and UK. Yet, a closer examination of some of the challenges with access to justice in Africa, which ADR is attempting to address, reveal, among other things, that the use of foreign procedures, principles and languages, in the formal justice systems, alienate many people and have contributed in creating a real barrier to the accessibility of justice. By using a comparative approach, the purpose of this article is to raise caution that although ADR may have useful components to improve access to justice in Africa, it cannot be viewed or introduced as a new concept coming from developed countries. Doing so, it perpetuates imperialistic attitudes, disempowers millions of people by disregarding their cultural practices and invalidates systems which have been in use for centuries.
\end{abstract}

Keywords: ADR, mediation, negotiation, arbitration, traditional conflict resolution.

\section{Introduction}

Further examination of justice systems in Africa reveals legal pluralism, made up of formal justice and traditional justice systems, which are predominantly used by the rural population. In countries such as South Sudan, traditional justice resolves as much as $90 \%$ of civil and criminal disputes (African Union Commission Report, 2015). These traditional justice systems, like ADR, utilize the same tools of mediation, negotiation and arbitration and have been in exist-
Nokukhanya NTULI

Specialist Ombudsman

Dispute Resolution, Compliance Advisor

Ombudsman (CAO) Washington,

Alumnus of the African Leadership Center

E-mail: Nokukhanya.Ntuli@outlook.com

Conflict Studies Quarterly

Issue 22, January 2018, pp. 36-61

DOI:10.24193/csq.22.3

Published First Online: 01/10/2018 
ence in African cultures for centuries. Yet, in many instances, they are overlooked, undermined, under resourced and only seen as relevant in transitional justice processes. Given the fact that foreign procedures, principles and languages, pose a serious challenge to access to formal justice in many African countries, what is the justification of introducing ADR, using "international best practices and standards" developed outside of Africa? Does this not run the risk of introducing, once again, concepts which are foreign and far removed from the cultural context with which most Africans are familiar and, therefore, result in ADR also being inaccessible? Furthermore, because mediation, negotiation and arbitration underpin all traditional justice systems, would it not be sensible, when introducing ADR in Africa, to adapt it to local cultural context and practices used in traditional justice?

This paper raises caution that although ADR may have useful components to improve access to justice in Africa, it cannot be viewed or introduced as a new concept coming from developed countries. Doing so, perpetuates imperialistic attitudes, disempowers millions of people by disregarding their cultural practices and invalidates systems which have been in use for centuries. It also does little to address the challenges of foreign concepts and language in the formal justice system, which creates a barrier to access to justice. Instead, when introducing ADR in Africa, knowledge should be drawn from the traditional justice systems to ensure that the final product, considers the cultural context and produces familiar ways of resolving disputes.

The paper will first briefly look at the rationale for promoting ADR. It will then look at the unique challenges of access to justice in Africa, through briefly examining the history of African legal systems and their relationship with traditional justice systems during colonial times. It then postulates that mediation, negotiation and arbitration are not new concepts in Africa, by looking at traditional justice mechanisms from different African countries. The paper will then briefly review the similarities and differences between traditional justice systems and ADR before moving to examine initiatives taken by African government to incorporated traditional justice practices into the formal justice system. It will also look at the challenges experienced in introducing ADR in the formal justice system and some the criticism of traditional justice systems.

\section{Justification for the use of ADR}

Disputes are part of human existence and relationships. How parties chose to resolve them is often dependent on the immediate circumstances and nature of the dispute. Parties may attempt to ignore the dispute; negotiate among themselves; get an independent third party to adjudicate, mediate or arbitrate the matter; or resort to using violence. All these, are valid ways of resolving disputes, depending on the circumstances. However, despite the different avenues available for resolving disputes, many countries preferred and have placed greater importance on adjudication through the courts. 
It was not until the litigation costs escalated and caseload became unmanageable that countries like the USA and England decided to pay closer attention to other forms of dispute resolution to improve access to justice. Although both countries had a history of using arbitration and mediation, its use before the 60 's was negligible. In the USA, the Patent Act of 1790 recognised the use of mediation. However, it was only in 1898 that Congress authorised the use of mediation for collective bargaining in New York and Massachusetts. In the 1920's, other states also began using alternative dispute resolution to deal with case backlog. Several states passed arbitration laws in 1920 and in 1926, the American Bar Association was set up to provide guidance to parties on how arbitration should be implemented (McManus \& Silverstein, 2011). The enactment of the Civil Rights Act of 1964, coupled with the woman's right movement and environmental challenges in the 60's, resulted in an increase in individual lawsuits, which flooded the courts and caused serious delays in resolving disputes (Goldberg, Sander, Rogers \& Cole, 2012). This further propelled the need to use ADR in courts. Today, mediation is the most commonly used form of ADR in the USA courts (Goldberg et al., 2012).

In England, it was the Woolf Report on Access to Justice of 1995 and 1996 which propelled the use of ADR. The report looked at how to improve access to justice and improve speed of resolving disputes, as well as accessibility to the courts (Genn, 2012). The report found that costs, complexity of procedures, as well as delay tactics by lawyers, were the greatest contributors to delays and lack of access to justice. The report recommended, among other things, a stronger focus on the use of ADR and that courts should be used as a last resort, after attempting other methods of resolving disputes.

This shift toward ADR resulted in ADR being promoted in many other countries, including Australia, Canada and some African countries, using "international best practices and standards" developed to professionalise the ADR profession.

Africa's rational for introducing ADR was no different to other parts of the world. ADR was seen as a possible solution to address lack of access to justice caused by case back$\log$, lengthy processes, cost of litigation and lack of human and financial resources. It was also seen as a way of simplifying court processes. Other challenges identified by the Institute for Security Studies (ISS), which hinder access to justice, included lack of court facilities in rural areas, where $62 \%$ of the people in Sub Saharan Africa still live (World Bank \& International Monetary Fund, 2013), low literacy levels', poverty, prohibitive costs of legal representation without sufficient legal aid, prohibitive cost of travel to the courts and, most relevant to this paper, the use of foreign, complex processes and languages, unfamiliar to many Africans (Bowd, 2009). The court processes seldom utilise restorative principles used in traditional justice systems, which people are accustomed to (Spinks, 2001).

The ISS' claim that access to justice is hindered by the use of foreign processes and languages in courts, can better be understood by looking at how the formal justice 
system came about in Africa. Many African countries inherited their legal systems during the time of decolonisation (Sium, 2010). These inherited legal systems, comprising of common law, civil law, religious law or hybrid systems, were far removed from the cultural systems which were in place in many African countries prior to colonialism. These legal systems were built on irrational, violent and malevolent practices, through which the colonial master achieved public control and deprivation of the colonised people (Sium, 2010). They were established by autocratic, racist and chauvinistic colonial governments, whose focus was de-indigenization, divide-and-rule and to ensure that, by using foreign languages, principles and procedures, Africans had no way of dealing with the injustices of the state (Davidson, 1992). Colonial powers regarded African tradition and systems as primitive and only appropriate for the natives (Joireman, 2001). In fact, when disputes arose, race was the predetermining factor for which legal system Africans were entitled to (South African Law Commission [SALC] Report, 1999).

When the independence was proclaimed, these systems were passed down with their foreign languages and processes, regardless of whether they were French, British or Portuguese and without consideration of local conditions and cultural context. They were soon described as "the machinery which had changed hands, but not its parts" (SALC Report, 1999, p. 113). For a very long time, the justice systems inherited by African nations remained as they were during colonial times and, in some instances, this continues to be the case (Berinzon \& Briggs, 2017). Little or no attempts were made to dismantle the oppressive systems of governance and replace it with an alternative system rooted in African culture.

The introduction of these foreign legal systems created tension with the existing traditional justice systems, which were meant to resolve disputes in pre-colonial times. The colonial administrations initially did not recognise traditional justice systems because they were perceived to be too primitive. However, they were later acknowledged as necessary to provide justice to indigenous people, where colonial infrastructure could not and in areas which were considered of little significance to the colonial administration, for matters such as marriage and land tenure. This approach resulted in the devaluing of traditional justice. In the meantime, a growing number of Africans were gaining exposure and education in the colonial justice systems through studying law in foreign countries. On their return, they too reinforced the notion of traditional justice as primitive and did not want to subject themselves to traditional justice systems (Davidson, 1992). The rejection of traditional justice by educated Africans had the effect of further relegating traditional justice and practices to be suitable only for those who were perceived as primitive, uneducated and living in rural areas where formal court infrastructure was not available.

This tension between traditional practices and foreign systems was heightened when the colonial powers were planning their withdrawal from the colonies. The educated 
Africans believed that they should be the natural successors of power because they were educated, civilised and understood constitutional law and issues of sovereignty (Davidson, 1992). The chiefs and traditionalist found this offensive and advocated for the retention of African culture. However, at independence, it was indeed the educated Africans who became successors of the colonial powers. Their beliefs about traditional African culture were now formed by the colonial powers. Therefore, they were better able to perpetuate the colonial legacy. This is best described by Edward Wilmot Blyden (an Afro Caribbean diplomat) who in 1900 wrote;

"Those who are instructed in the English language, are taught by those from whom they have received their training, that all native institutions are in their character, darkness and deprivation, and in effect only evil and evil continually.... the Christianised Negro, looks away from his native heath. He is under the curse of an insatiable ambition for imitation of foreign ideas and foreign customs" (Davidson,1992, p. 43).

Sadly, this tension between traditional African practices and Western practises continues, not only in the justice field, but also in many other sectors.

Another factor that has created lack of access to justice, in some African countries, is the destruction of judicial institutions during civil wars. Institutions, that were already not conducive to providing justice to citizens, were further destroyed during civil conflicts, either through physical damage to buildings or loss of judicial officials, through death or immigration. With all the challenges highlighted above, initiatives to strengthen access to justice in Africa still focus primarily on the formal justice sector (judiciary, police, prosecution) with little or no regard to African heritage, culture and history.

\section{Overview of traditional justice in Africa}

Over many centuries, citizens in many African countries have relied, and continue to do so, on traditional justice systems to resolve disputes. In pre-colonial times, many African communities organised themselves according to kingdoms and clans, each with its own dispute resolution systems to resolve intra and inter-community disputes. For centuries, traditional justice systems utilised forms of negotiation, arbitration and mediation to resolve disputes (Mutisi, 2011). These systems were rooted in the culture and history of the societies and built around the concepts of reconciliation, accountability, truth-telling and reparation (Huyse \& Salter, 2008).

All types of disputes were resolved using traditional justice, including theft, family disputes, commercial disputes, water and land rights disputes and other criminal matters, such as rape and murder (Radar \& Karimi, 2004). In many communities, transgressions were not regarded as individual failings, but rather as a collective failure by the family, clan or community, to prevent individuals from committing the transgression (GIZ, 
2013). Therefore, transgressions and disputes were collectively owned and prioritised for urgent resolution within the community.

Local actors and persons with authority, such as community elders, family elders and/or the chiefs and kinship, were tasked with managing, making decisions and resolving daily disputes. These local actors were selected based on their reputation, position, wisdom, patience, familiarity with local customs, being good listeners, impartiality and experience. In resolving disputes, they maintained social cohesion in their communities and ensured implementation of agreements reached to improve relationships (GIZ, 2013).

The process of dispute resolution was a consultative and collective effort, involving various community stakeholders and often held at a neutral, public and open space such as the village square, under a tree or an open hut (Umunadi, 2011). Preparation for the dispute resolution processes involved consultation with the parties, invitation of appropriate persons, gathering material for rituals (such as sacrificial animals), local brew for consumption after the process and selecting a date that does not clash with events such as the market day or farming (Umunadi, 2011). Parties were afforded an opportunity to express themselves without direct confrontation and members of the community, not party to the dispute, were also able to make representation during the dispute resolution process. This ensured that, no matter the status level, everyone who felt they had something to contribute to the dispute for the good of the community, was given an opportunity to speak. The public nature of the dispute resolution process created social pressure on the disputants and this played a strong role in ensuring compliance with the outcome. Disobeying the final ruling was tantamount to disobeying the whole community and resulted in a party being ostracised (Spinks, 2001).

The use of mediation and arbitration varied depending on the society and the seriousness of the case (Grande, 1999). In some instance, the role of the elders was to mediate the dispute and assist parties to come to their own decisions. In other instances, the last word belonged to the elders or authority figures, thereby making the process closer to arbitration. After deciding, the elders or chief would still obtain the consent of the disputing parties and of the community, to legitimise their decisions. In other times, the king or chief would consult with his counsel before deciding (Grande, 1999).

The main purpose of traditional justice systems was to create consensus, bring reconciliation and to maintain social cohesion within the community. The process focused on the victim rather than the offender (Elechi, 2004). The punishment was meant to bring healing to the victim, the victim's family and the community. This was often in the form of compensation, which included an apology (often a public apology) to the victim and/ or atonement by the offender to the victim and the community (Elechi, 2004). Unlike the Western forms of justice, which seek to establish guilty then issue a punishment with little reference to the victim, or seeking to reintegrate the offender back into the com- 
munity, the traditional justice approach encouraged peace and reconciliation, thereby enabling the offenders to admit guilt knowing that forgiveness, re-integration and social cohesion govern the processes (Chereji \& Wratto, 2013). In African tradition, the belief was that all human beings are important and that they are naturally good, that human beings can change and, consequently, deserve a second chance.

Central to the process of dispute resolution were food and spiritual rituals. The dispute resolution process started and/or concluded with an offering of an animal to the ancestors. Certain rituals were performed after the process, such as dancing, eating and drinking traditional beer. Even the compensation was often an animal offering, food or drink.

These practices are still in place in many countries and more than half of the population in sub-Saharan Africa still rely on them to provide access to justice. In rural areas, only $36 \%$ of the population would consider referring the mattes to court (Loschky, 2016). Their first point of call when they have disputes is the traditional justice mechanisms or religious leaders. Below are a few examples from various parts of Africa that embody some basic principles of dispute resolution described above, focusing on reconciliation, healing and social cohesion.

\section{Ethiopia}

The Horn of Africa is home to Lucy, one of the oldest early fossils (Australopithecus afarensis (AL 288-1), (Haile-Selassiea et al., 2010)dating back 3.2 million years. This region is also home to the Afar people, who are one of the first inhabitants of the Horn of Africa in Eretria, Ethiopia and Djibouti and have a long-standing history of self-governance. The Afar people utilise the Madáa system of governance which prescribes, among other things, how inter and intra-clan disputes are to be resolved, based on customary laws which are passed down orally through the generations (Gebre-Egziabher, 2014). The society is divided into clans and sub-clans and, although the application of the Madaa varies slightly from clan to clan, the general principles and practices have been the same over the years. The elders or clan leaders are tasked with resolving disputes using arbitration (Maro) or mediation (Mablo) (Pankhurst\& Assefa, 2008).

The "Maro" is used to resolve all serious violations, except for divorce, marriage and inheritance, which are left to the Sharia Law. The process is conducted at a venue, usually an open space under a tree, near a water source and centrally located for all parties. In attendance is the judge (the "Mekabon") or several judges, depending on the seriousness of the offence, an elder with a good reputation, the disputing parties, witnesses and a duplicator, all of them sitting in a circle under the tree. The accused also has a guarantor who undertakes to ensure that the accused accepts the outcome. The guarantor provides the food and drinks for the ceremony (Pankhurst \& Assefa, 
2008). Once the proceedings begin, the parties are given an opportunity to state their case. After that, the duplicator summarises and rephrases everything the parties have said in a culturally acceptable manner. This ensures that parties feel they were heard (GIZ, 2013). After the parties are heard, a decision is made about the appropriate punishment, if applicable. The punishment varies depending on whether the offence was intentional or accidental. Because offenses are seen not as individual offenses, but as a collective responsibility of a clan, the clan collectively makes compensation (Tesfay \& Tafere, 2004). At the end of the proceedings, the parties celebrate using the food and drink provided by the guarantors.

For minor disputes, such as light physical injury, theft and insults, the Afar people utilise the mediation process, "Mablo", which is informal and managed by the elders, to provide quick and efficient resolution to disputes (Mu'uz, 2013). In cases of severe inter-clan offenses (such as inter-clan murder), the Mablo is also utilised, often using neutral mediators (Isi) and judges (Mekabon) who are known and respected people, from a clan neutral to the dispute (Sansculotte-Greenidge \&. Fantaye, 2012). Once the identity of the murderer and the deceased is identified, the Isi and Mekabon hold the first meeting with the clans involved. At this meeting, a cow or camel is sacrificed to demonstrate commitment by the parties to the process. The purpose of this process is to contain the dispute so that it does not escalate into violence and to require the disputing clans to take an oath - not to revenge for 40 days, until the Mablo process has been finalised (Sansculotte-Greenidge \& Fantaye, 2012). The Afar do not bury a victim until the animal has been sacrificed. Once the burial has taken place, the investigation is conducted and concluded. After that, inter-clan negotiations commence and an open meeting is held for the verdict. Often, the victim's family is asked whether it seeks capital punishment for the crime. This is largely a symbolic gesture. To prevent inter-clan feuds, the victim's family almost always choose compensation, which is predetermined by the Madaá for every offence. If a family chose to retaliate, the elders of the clan would be sent to dissuade the family by begging. Where a family chose to go ahead with revenge despite the elder's begging, this leads to loss of clan membership and ostracising for up to seven generations (Tesfay \& Tarefe, 2004).

If the family chooses to forgive, the meeting ends with the slaughtering of an animal along the road so that passer-by's may learn the lesson of forgiveness and reconciliation. The principle behind the dispute resolution systems of the Afar people is to make peace and central to this process is forgiveness, respect for the elders and transfer of resources of compensation (Tesfay \& Tarefe, 2004).

This dispute resolution system is still the preferred system for the Afar people. Decisions by formal courts are not as effective in resolving conflicts and maintaining peace as the traditional justice system, due, largely, to the unfamiliar procedures and use of people unknown to the Afar communities (Tesfay \& Tarefe, 2004). 
The Department of Justice in the Afar Region in Ethiopia estimates that as much as 90-95\% of people in the Afar region utilise traditional justice systems. According to Mr. Ge'ase Ahmed, courts coordinator in the Southern Red Sea in Eretria, it is rare for the Afar to file a suit at government court or any law enforcing government body. Court cases are considered a taboo that violates the long-standing customs of Afar communities (Ghebrehiwet, 2010).

\section{Liberia}

Liberia is the oldest independent republic in Africa, established by the free slaves repatriated from the USA and the West Indies in 1847. From the onset, the free slaves ruled the country to the exclusion of the $90 \%$ indigenous population (Huyse \& Salter, 2008). This gave rise to multiple civil wars (1989-1996 and 1999-2003) which resulted in the breakdown of the already exclusive and weak justice system. Fortunately, the Liberian people, much like other African countries, had existing traditional justice systems in place, namely the Sassy Wood (trial by Ordeal), the Palava Hut and Sharing the Kola Nut (Huyse \& Salter, 2008).

The Sassywood, which is a controversial dispute resolution system and was recently banned by the Liberian government, is an adjudicative process that rests on the belief that the judgement of guilt, is in the hands of ancestral spirits. It was reserved for serious crimes such as murder, rape, theft and witchcraft. The trial was conducted either by drinking a bitter drink or by using a hot machete. In the case of the bitter drink, the drink was made from an indigenous bitter plant and given to the accused to consume. Regurgitating the drink demonstrated innocence, whereas failure to regurgitate, was indicative of guilt. Where the machete was used in place of the bitter drink, the machete was placed on the fire until it was red-hot. It was then placed on the accused's leg. If the accused moved the leg or was burnt, it was an indication of guilt; if nothing happened to the accused, this indicated innocence (Chereji \& Wratto, 2013).

If the accused was found guilty using either of the above methods, the accused would be publicly shamed and would have to repent and make a public apology before paying compensation to the accuser. After the compensation was paid, the offender was reunited with the victim and the community. In the case of murder or witchcraft, the offender could be ostracised from the village. Although the Sassywood has been banned by the government of Liberia, it continues to be used and trusted by many.

Other traditional dispute resolution systems used in Liberia are "sharing the kola nut" and the "palava hut". In the case of sharing the Kola Nut, when someone is accused of wrongdoing, the elders investigate. If the accused is found guilty, he/she is requested to ask for forgiveness from the victim and make amends through compensation. However, prior to making compensation, the offender offers a kola nut to the victim. If the victim takes the nut and puts it away, it indicates that the victim is not willing to forgive. 
However, if the victim takes the nut, bites it and offers the other half to the offender, it is a sign of forgiveness. Compensation, in the form of a goat, cane juice or a chicken, was then made to the victim after the kola nut has been shared. This system is based on forgiveness and follows a local saying "let bygones be bygones" (Pajabo, 2008).

The Palava Hut, like sharing the Kola Nut, focuses on reconciliation. It is typically held in a round hut where villagers gather to resolve disputes under the leadership of elders. It is believed that ancestral spirits are present during the process and thus, when discussions are held in the palava hut, no one is permitted to leave until the dispute has been resolved. The palava hut is used for all types of disputes, including inter-village disputes (Pajabo, 2008). Its purpose is to seek admission of guilty from the offender, an apology, then forgiveness from the victim. Once the apology has been accepted, the offender pays compensation to the victim's family, in the form of Cane juice, a chicken, palm oil, rice or a goat. On conclusion of the process, the offender and the victim share a plate of food (Danso, 2016). Cane juice is poured out to invoke the ancestral spirits. It is believed that by invoking the spirits, the parties are likely to be true to their word and respect the resolution, otherwise they open themselves up to the wrath of the spirits (Danso, 2016). The offender is often given advise by the elders to prevent a repeat of the offence, while the victim is often praised for accepting the apology.

Where a serious offence has taken place (such as murder), the process followed is like that of the Afar people in the Horn of Africa. Before the dispute resolution process takes place to deal with the murder, both parties are required to observe a grieving period. This period is also used to calm tempers so that the dispute resolution process is more effective. The offender is kept in a safe place to prevent retaliation from the victim's family. An animal is slaughter and the blood poured on the victim's grave to ensure that the ancestors accept the victim's spirit (Danso, 2016).

The dispute resolution process proceeds after the grieving period. A meeting is held where the offender is given a penalty and is required to make compensation. The compensation is also seen as a cleansing process to rid the offender of the evil spirits that lead to the murder (Danso, 2016). The victim and offender's families are then required to share a meal and eat all the food provided to them to complete the cleansing process. Once the cleansing is completed, the offender makes a public apology and presents the victim's family with a white plate which is a symbol of remorse and atonement. Once the victim's family accepts the plate, the offender is banished from the community for several years. The number of years are dependent on the gruesome nature of the crime and whether it was a mistake or intentional (Danso, 2016).

The Palava hut is so widely used in Liberia, that in 2013 the government launched a National Palava Hut programme as part of the recommendations that emanated from the TRC process and report to promote access to justice. 


\section{Burundi}

The Bashingantahe are responsible for settling disputes at all level. The term, which means men of integrity (Huyse \& Salter, 2008), goes back as far as the $17^{\text {th }}$ century. The Bashingantahe are made up of elders with irreproachable morality and they have three essential roles - mediation, reconciliation and arbitration. The Bashingantahe are driven by the principles of neutrality, impartiality, transparency, honesty, equality and service. When a dispute arises, mediation is always seen as the first point of call conducted by an umishingantahe (singular). Where no resolution is found during mediation, the matter is referred to a counsel of Bashingantahe to find a compromise. The Bashingantahe try to find a resolution by counselling the parties and proposing mutual forgiveness and reconciliation, instead of compensation. Together with mediation, this process is seen as a compulsory step for all conflicts. Where the process drags out for a long time, the Bashingantahe assume the role of arbiter. They hand down judgement and their decision is binding on the parties. If the party is dissatisfied with the finding of the Bashingantahe, they may appeal the matter in a formal court (Huyse \& Salter, 2008).

\section{Mande People in West Africa}

Many traditional justice systems utilise similar practises and focus on reconciling disputing parties as well as maintaining social cohesion. However, some have very distinct characteristics that make them unconventional and unique. The Mande people, who spread over large parts of West Africa, have some very innovative ways of resolving a conflict. The storyteller, musician and historians, praise singer and poet, also known as Jeli (Griots) among the Mande people in West Africa, plays an important role in resolving disputes. The Jeli, who according to the caste system, are historically considered of lower social status than the nobles, occupy an unconventional position of influence in the community (Hoffman, 2000).

Their prominent role as entertainers means that a wedding or funeral without them is unthinkable. Their role as praise singers, historians, genealogists, storyteller and poets, makes them a repository of knowledge, history and culture, which is passed down orally through a hereditary lineage. They are the guardians of cultural practices and knowledge in the community and they communicate this culture and knowledge through music and words. This role has made them indispensable and has earned them admiration and respect within the society (Hoffman, 2000). Historically, they also provided counsel to the kings and the community. Politicians have also used them to convey political messages during electoral campaigns.

Because of their in-depth knowledge of genealogy, culture and custom, they mediate family and community disputes. They claim that because culture and custom is passed down over generations through them, they know the oaths that the ancestors of the disputants made to one other (Ebine, 2017). The Jeli's position of influence in society, 
their ability to speak freely and criticise even high-ranking officials, without fear of retribution, means that disputants often seek their approval and they are, therefore, well placed to be effective mediators. (Chikwanha, 2008). Their role and ability to shame, gives them power to persuade the parties to reconcile. Shaming is an effective tool, as it can result in a person being marginalised.

Another unique feature of the Mande dispute resolution mechanisms is Sanankuya, also known as joking relations or cousinage, which are a big part of the conflict resolution culture in Senegal, Guinea, Mali and Gambia (Davidheiser, 2006). Sanankuya relies on pre-existing relationships between people from the same clans, ethnic group, religion or profession. Those in a Sakankuya treat each other as though they are cousins or close family members who can exchange familiar jokes or insults related to some stereotypes or historic facts about the particular clan, ethnic group, religion or profession, (Smith, 2004) which otherwise would be offensive and intolerable in a different setting. This way of interacting is perhaps motivated by the Tuareg proverb "laughter gives confidence, its absence causes conflict."

Rather than suppressing these stereotypes, they are neutralised by expressing them through humour. What is important in the exchange is that each party feels superior to the other and, therefore, can insult or joke about the other. If the banter is about being a slave, both parties will consider the other their slave and, in that moment of banter, there is a reversal and balancing of a relationship of domination (Smith, 2004). It allows for unconventional interaction between parties, regardless of hierarchy. A commoner may insult a chief and a grandchild may insult a grandparent. In that moment, neither take offence because the exchange is all done in gest ( $0^{\prime}$ Bannon, 2008). The use of such banter creates a sense of community by revealing a sense of equality in difference, through the use of humour.

The use of Sanankuya to resolve disputes relies heavily on culture and custom. The aim of mediation in the context of this region is to use the customs of humour, to persuade the parties to forgive and settle their dispute, rather than a facilitative tool for parties to discuss and resolve their disputes, as is the case in ADR. Mediators often remind the parties of the interpersonal ties that they, as mediators, may share with the disputants, including family, historic, religious and ancestral ties(Smith, 2004). Where there is no direct kinship, mediators rely on ethnic, communal and friendship ties to create the kinship. Mediators often evoke sanankuya to persuade the parties into having a cooperative interaction and reciprocal banter. This is transformative because it changes the attitude of the disputants.

Typically, the mediator evokes the joking relationship between her/himself and the disputants. If they respond favourably by engaging in the banter, this creates a bond that enables the mediator to encourage the parties to forgive and reconcile. If the disputants challenge the banter initiated by the mediator, the mediator will diffuse the 
situation by pointing out that the disputant is behaving like one of his/her relatives, thereby creating a joking kinship. The emphasis of the mediation is not to reconstruct the facts of the dispute, but rather to focus on the present and how the parties can move forward in a reconciliatory manner.

Mediation using joking relations is not always successful. However, where there are strong historic ties between the parties, the outcome is often positive and often results in forgiveness and reconciliation of the parties.

\section{Distinction between traditional justice and ADR}

Like ADR, mediation, negotiation and arbitration underpin traditional justice systems. Both systems are less formal and adversarial than the court processes and often less time consuming and, therefore, less costly. They both utilise a third party to assist the disputing parties to resolve disputes. The parties are active participants in the process and the third party is expected to be impartial and to handle disputes in an even-handed manner. However, despite the similarities, there are distinct features of traditional justice that make it very different from ADR.

\section{Neutrality}

In ADR, neutrality is important. The third party is appointed based on their training and experience in handling the ADR process. They are expected not to have an interest in the outcome of the dispute and not to have a relationship with the disputing parties outside of mediation. However, this is not the case with traditional justice. Traditional justice utilises third party elders, chiefs or other authority heads, who are well known and respected by the community for their wisdom. These individuals are part of the community and often know the disputants or their family or clan, outside of the process. Because the purpose of the dispute resolution process is to maintain social cohesion and reconcile the disputing parties, the elder or chief always has a vested interest in the outcome of the dispute, because it affects more than just the disputants. Therefore, the approach to dispute resolution is more directive in search for a compromise than it is in ADR. This also goes away with the notion of self-determination. In ADR processes, the parties to the dispute are encouraged to come to their own decisions about the outcomes they seek from the process, without influence from the third party. This is not the case in traditional justice processes.

\section{Confidentiality}

ADR is held in private to preserve confidentiality of the parties and issues discussed. This is one of the things that appeals to many disputants about ADR. In mediation, parties can make admissions without fear that the information will be shared with the other party, thereby saving face and preserving the party's reputation. In arbitration, parties 
can choose to deviate from strict legal processes to create a suitable process. Unlike $\mathrm{ADR}$, confidentiality is not a prerequisite of traditional justice processes. In many communities, an offence by an individual is perceived as a failure by the community and, as a result, the process of resolving disputes is a collective effort. Often, it is conducted in an open, public place, where community members were free to attend and weigh in on the dispute if they believe it affects them. When the elders are convening the meeting, they ensure that it does not clash with market days to enable community members to attend the proceedings. The public nature of the process creates transparency, accountability, builds trust and serves as a lesson to the community on reconciliation, forgiveness and atonement. The only instance where confidentiality is considered, in certain communities like the Afar, is rape. Confidentiality is important to protect the reputation of the person who has been raped and to prevent them from being ridiculed by community members.

\section{Distinction between mediation and arbitration}

Traditional African justice does not always clearly distinguish between arbitration and mediation the way ADR does. Hence, even in mediation processes, parties expect the mediator (elder or chief) to decide or give guidance and direction for the solution. In some instances, where the authority or elder gives direction during a process, they may still seek consensus from the parties and the community to validate the decision. Other times, they may consult with a traditional counsel before making the decision. Cultural and historic roots govern traditional justice systems. Often, there are set precedents on how certain disputes will be resolved and how much compensation the offender should pay. Even where the parties voluntarily reconcile, the third party still decides on compensation. The traditional justice process is closer to Med-Arb, where the mediation and arbitration are used to reach resolution.

\section{People focused}

ADR often focuses on separating people from the problem;focusing on the issue and not on the people (Fischer \& Ury, 1991). However, traditional justice focuses more on the people and the relationships. Because of the need to preserve social cohesion and the view that an offence by the individual is seen a failure of the entire clan, the resolution of disputes is primarily focused on relationships. This is sometimes to the extent that during the dispute resolution process, the parties are not given an opportunity to articulate their side of the story, but rather encouraged to look forward and forget about the past, as is the case with the use of joking cousins in West Africa.

\section{Rituals}

Traditional justice systems all have some form of rituals associated with them. In some processes, there is a strong belief in the presence of ancestors during the proceeding, 
which can be used as a pressure point for disputants to settle. In processes like the palava hut and sassy wood, ancestral presence during the process is at the heart of the process. Other parts of the dispute resolution rituals include slaughtering an animal, either before the process begins or at the end of the process, dancing, drinking and eating, which are all integral parts of the process. Often, they signify the restoration of community relations, reconciliation and forgiveness. These rituals are completely absent in ADR.

\section{Can ADR enhance access to justice in Africa?}

In many instances, ADR is introduced as an alternative to the court process and touted as having the potential to make justice more accessible. This may be true for those people who already have access to formal justice. However, for those people in the rural parts of Africa who have no court infrastructure and struggle with the foreign processes and languages used in formal justice system in urban areas, introducing ADR into the formal justice system,does not change much. Furthermore, research conducted in the European Union and Australia demonstrates that merely introducing ADR, even in the formal justice system, is not enough to guarantee better access to justice.

According to an EU study published in February 2014, the introduction of mediation to the formal justice system has not yielded the expected outcomes of creating better access to justice. In 2008, the EU introduced a mediation directive (Directive 52/EC) "to facilitate access to alternative dispute resolution and to promote the amicable settlement of disputes by encouraging the use of mediation and by ensuring a balanced relationship between mediation and judicial proceedings" (European Parliament and Council, 2008). The rationale for introducing the directive was based on mounting concerns about court costs and congestion and the need to create better access to judicial and extra judicial dispute resolution systems. However, the results were disappointing. Mediation was used in less than $1 \%$ of cases in the EU, during the period under review. Only Italy demonstrated a high usage of mediation, with over 200,000 mediation matters initiated annually. Of these, $50 \%$ were settled. The next top three countries have managed to grow mediation in the EU to just over 10.000 cases annually, with the rest of the EU countries seeing less than 2,000 cases per annum. The report also found that having an element of compulsion, was what resulted in Italy, having such positive results. When mediation stopped being compulsory in Italy, the usage of mediation dropped to almost zero (Rebooting the Mediation Directive, 2014).

This study demonstrates that merely introducing ADR as part of a justice system was not enough to achieve the desired outcomes in Europe. The successes which were achieved in Italy, were a result of mediation being mandatory. Where mediation was not mandatory, its introduction into the justice system yielded poor results.

Also, relevant in determining whether ADR may be beneficial in Africa is a study conducted on ADR in Australia. The study sought to establish how the Aboriginal Communities, 
who like Africans, are accustomed to a collective and reconciliatory way of resolving disputes, have embraced the introduction of ADR into the justice system (Ciftci \& Howard-Wagned, 2012). The study reveals that,often, the Aboriginal communities feel alienated by the ADR process and that merely introducing ADR into the justice system is not enough.

The 1990s Australia, like other developed countries, saw a growth in the use of ADR and the laws mandating its use. However, research soon revealed that the use of ADR was not necessarily a good fit for the Aboriginal community. Aboriginal people believe that conflicts should be treated like property and guarded jealously so that they are not stolen from the community, as is the case with criminal offences which have become offenses against the state and require little effort on the part of the disputants to resolve (O'Donnell, 1995). ADR is perceived as privatisation of disputes, which is unacceptable to the Aboriginal community. Resolution of disputes in the Aboriginal community is a public affair because matters are often of importance to the wider community. This enables families and interested parties to be aware of the negotiations, outcome and settlements, so that they can influence the process if required (O'Donnell, 1995). Therefore, principles of ADR, such as confidentiality,are perceived by the Aboriginal community as problematic. The community also feels that utilising a neutral third party diminished the role played by the elders in resolving disputes. This presents a challenge for the Aboriginal community because the neutral third party does not know the parties and has no interest in building communal relationships (Ciftci \&Howard-Wagned, 2012). The research also concludes that the facilitative and determinative type of ADR can be alienating to indigenous communities, as it is prone to systematically favour the more powerful elite parties and perpetuate the dominant Western culture. This is because the style of ADR and language used still represents the Western dominant culture. Furthermore, the Aboriginal community have little trust in the formal justice system because of the historic injustices which the justice institutions have displayed against them. Therefore, ADR is received with the same suspicion that the community has for the formal justice system.

Because of these observations, Australia put in place a range of initiatives,such as the Community Justice Programme and Care Circles(in the family division for child protection), to incorporate the various aspects of indigenous justice into the mainstream justice system. The care circles are used once a magistrate has determined that a child needs protection. The elders in the community convene a public meeting where the community is seated in a circle to discuss issues related to child protection plan and to determine the best solution in a matter for the child and the community at large. The care circles closely resemble the dispute resolution processes that the community is accustomed to, but they combine the use of formal justice (magistrate) with traditional justice (elders). 
In Africa, where most of the population still prefer traditional justice systems, the introduction of ADR into the formal justice system may not have the desired results of creating better access to justice,as seen in the Aboriginal community in Australia. In Liberia,for instance, where a survey conducted in 2009 found that only $3 \%$ of criminal and civil disputes were taken to a formal court and over $40 \%$ sought resolution through informal mechanisms (Uwazie, 2011),introducing ADR into the formal justice system may only cater for the $3 \%$ already using the formal justice system.

In South Africa,the government set up the Equality Courts in 2003 to create better access to justice for the marginalized and poor to deal with issues of systematic inequality and discrimination (Kruger, 2011). These courts were set up to be simple, cheap and informal so that parties feel more comfortable with the process and do not need to be represented by a lawyer. However, due to the poor usage of these courts, the government began decommissioning them. Of the 220 designated courts in all the provinces, less than 700 cases were filed between 2003 and 2006 and, in the same period, no case was filed in the rural areas(Kaersvang, 2008). The reasons for the poor performance of these courts is unclear due to the lack of sufficient data to conduct proper studies. However, this further point out that access to justice will not improve by merely setting up more court or simplifying the formal justice system. There is a need for justice systems that are sensitive to the historic injustices and imbalances and that take into consideration cultural practices and values of the people they are intended to serve.

\section{Merging of justice systems}

the promotion of ADR has grown in many African countries. These countries have made great strides to incorporate the use of ADR in various forms in the formal justice system for the purposes of resolving disputes and creating better access to justice. Court connected mediation and the use of arbitration are becoming common occurrences in many African justice systems. Some African countries have taken things a step further by introducing ADR into the upper court of the formal justice system and merging traditional justice systems into the formal justice system so that they are used at the lower court level to become the first court of instance in resolving disputes.

The United Nations encouraged this approach in 2004 when Koffi Anan acknowledged that due regard should be given to traditional justice systems in the settlement of disputes to help them continue their vital role of resolving disputes, but to also help traditional justice conform with international standards. Incorporating traditional justice into the formal justice system has proven to be a successful way to create better access to justice and to reduce case backlog in some countries because it is home grown, locally owned and culturally embedded. 


\section{Rwanda}

Perhaps the best-known example of this is the Gacaca courts in Rwanda, used to resolve disputes arising out of the 1994 genocide. At the end of the Rwandan genocide, the number of people detained for genocide related charges was as high as 125,000 . This meant that prisons were not easily able to accommodate all the detainees. Some died in prison before their cases were heard. This is because the country was faced with a serious capacity challenge after the genocide. Before the genocide took place, there were 785 judges in Rwanda. Only 244 remained after the genocide because they either had been killed or had fled the country. Only 12 prosecutors remained out of 50 before the genocide and 22 criminal investigators remained out of a former 197 (United Nations, 2000). This affected the entire judicial system by creating backlog not only for genocide related matters but also other regular crimes.

The Gacaca court system enabled communities at the local level to elect judges to hear the trials of genocide suspects accused of all crimes, except planning of genocide. The system was based on the traditional justice system of settling disputes using judges (inyangamugayo) who were people within the community, with great integrity and influence. It was estimate that using the formal justice system to deal with genocide crimes would have taken more than 200 years to put all the accused through trial (Kayigamba, 2012). The Gacaca courts were estimated to have heard approximately two million cases between 2001 and 2012, with the process costing an estimate of $\$ 40$ million. The use of Gacaca's resulted in considerable cost and time saving, compared to the International Criminal Tribunal of Rwanda (ICTR), which heard its first case in 1997 and by 2012 had only completed 69 cases, with a staggering cost of $\$ 1$ billion (Kayigamba, 2012).

Rwanda has also gone further to reinstitute and recognise the "comite y'abunzi" (abunzi). These "comite y'abunzi" were mandated by Article 159 of the Constitution and the Organic Law No. 31/2006 and Organic Law No. 02/2010/OL. The law was amended in July 2016 (Abunzi Act, 2016), following the amendment of the Constitution in 2015. Abunzi is a Kinyarwanda word meaning "those who reconcile" and it provides for a system that utilises trained local mediators to resolve disputes in communities. The Abunzi is a traditional dispute resolution mechanism, which has been modernised, to provide mediation for civil and criminal disputes of values not exceeding 3 million Rwandan Francs at Cell and Sector level. The abunzi' was officially launched in 2004 and forms part of the local government structures falling under the administration of the Ministry of Justice. The Abunzi committee is made up of seven members, all of whom must reside within the Cell and Sector. They are persons known for of integrity and their ability to mediate disputes. The lawa lso requires that $30 \%$ of the committee members to be women.

In conducting the dispute resolution process, the law requires the Abunzi to take local culture and custom into account, both when evaluating the parties' testimonies and 
when making decisions, provided the local custom and culture, do not clash with any laws (Abunzi Act, 2016). Like the traditional justice mechanisms described above, the process is conducted in an open, public place. Parties give testimony before the abunzi, after which testimony from any other person who feels affected by the dispute is also permissible. The Abunzi encourage the parties to reach a compromise and reconcile their differences in an attempt to maintain unity and social cohesion. If the parties fail to reconcile, the Abunzi makes a decision. A party that opposes the verdict of the Abunzi at Cell level may appeal to the Abunzi at Sector level. Where the party opposes the verdict of the Abunzi at Sector level, they may file an appeal with the primary court Abunzi Act,2016).

According to the Rwanda Governance Advisory Council (RGAC), the Ministry of Justice in Rwanda has approximately 32.400 Abunzi Committee members across 2,150 cells and within 30 districts (Mutesi, 2011). Some of the achievements of this initiative are that there has been a 75\% drop in land disputes referred to court for adjudication. A survey conducted by Transparency International Rwanda reported that $81.6 \%$ of the communities are satisfied with the use of these committees to mediate matters because it promotes access to justice ('Rwanda: Abunzi Must Jealously Guard Their Reputation', 2004). On the other hand, in comparison with the ordinary courts, the most highlighted indicators are the $86.7 \%$ reduction of time spent to settle cases, an $84.2 \%$ reduction of economic costs of cases in cell and sector level and an $80 \%$ mitigation of disputes between parties (Nsanzimana, 2012).

\section{Zimbabwe}

When Zimbabwe gained independence in 1980, a process of overhauling the judiciary began. The Customary Law and Primary Court's Act was enacted to introduce a new judicial structure of upper and lower courts (Spinks, 2001). The lower courts were constituted by village courts and community courts which were used to appeal decisions of the village court. These lower courts, whose operational model is based on tradition justice systems, have jurisdiction over customary issues. Appeals of community court decisions go to the magistrate courts (Spinks, 2001).

The proceedings in the lower courts share similarities with traditional justice systems in that they are informal, flexible, simple and allow for public participation. The aim of these courts is to provide access to justice to people in the rural areas, based on customary practise which they are accustomed to (Saki \& Chiware, 2007). The courts focus on resolving disputes in a manner that promotes social harmony within the community. Disputants present their own cases without the need for lawyers and may present any evidence they believe to be relevant to the case (Spinks, 2001). The proceedings are public and anyone who believes that they have something to contribute towards the case may make presentation. 
A further overhaul of the judicial system was undertaken in 1990 to modify the lower court by making community courts the customary division of the magistrate court. Headmen courts were made the courts of first instance, with the Headman and any other person appointed by the Minister of Justice as presiding officers. Chief Courts became the community courts that could hear appeals from the court of first instance. These are presided over by the local chiefs.

\section{Uganda}

Uganda utilises Local Council Courts, which are less formal and complex than higher courts. The judicial function of these courts developed during the war of the National Resistance Movement Army (NRM) between 1981-1986 in the Luwero Triangle (UNDP Report, 2005). The structure was set up by the NRM, to create governance structures where none existed. When the NRM came into power, they sought to formalise and democratise the structures established during the war.

In 1988, the NRM formally gave judicial powers of civil matters to the Local Council Courts. Up until then, these adjudication powers rested with the chief in the village, parish and sub-county level. The Local Council Courts, were formalised by the Local Council Court Act of 2006. The main objective was to achieve a more accessible courts system that utilised cultural norms and provided a dispute resolution mechanism with which the locals were familiar. These Local Council Courts were also closer to the rural people (UNDP Report, 2005). They were established in every village (LC1), parish (LC3) and sub-county level (LC5) with jurisdiction to handle civil matters up to a total value of 2 million Ugandan Shilling (Adonyo, 2012). In 2007, the Government of Uganda and the Lord's Resistance Army (LRA) signed a pact to promote the use of traditional justice mechanisms for the purposes of accountability and reconciliation (Huyse \& Salter 2008). This was to ensure that the practises of traditional justice which existed before British colonial rule were incorporated into the justice system to make it more accessible to people.

In keeping with the traditional African culture, the courts can give the victim relief in the form of reconciliation, compensation, restitution and an apology. The court utilises local languages during proceedings and prohibits the representation of parties by lawyers, except in cases where the bylaws have been broken.

The LC courts have become the most significant provider of justice for millions of Ugandans, especially in Northern Uganda (UNDP, 2005). At least 70\% of people indicate that they have access to the local council courts and that $80 \%$ of all matters are resolved within the requisite 30 -day period.

However, the local council courts are not without challenges. One the key challenges faced by the local council courts is that the presiding officers receive very little pay for 
presiding over matters. This creates a breeding ground for corruption. The parties may be charged more money to file their matters so that the presiding officer can be paid more. The presiding officer may also solicit funds from parties' thereby compromising impartiality.

\section{Challenges when introducing ADR}

The growth of ADR in its present form on the continent is certainly an overall positive step for the promotion of access to justice in the formal justice system. Ghana, South Africa and Uganda are among the countries in Africa who have recorded remarkable success in using ADR in the formal justice system. The Commercial Division of the High Court of Ghana under the High Court Civil Procedure Rules (C.I. 47) uses mediation as a mandatory pre-settlement procedure. In 2000, a pilot programme on court annexed mediation was put in place in Ghana, and it achieved an average settlement rate of above $60 \%$ on all cases mediated.

In South Africa one of the flagship uses of ADR is the Commission for Conciliation Mediation and Arbitration (CCMA) whose functions is to conciliate/mediate and arbitrate work place disputes as set out in the Labour Relations Act No. 66 of 1995. And in Uganda, the Statutory Instrument 2013 No. 10. The Judicature (Mediation) Rules 2013, which enables the use of mediation for civil actions filed in the High Court of Uganda and other subordinate court to the High Court has enabled court connected mediation to take off in Uganda. Therefore, ADR certainly has a role to play in enhancing access to justice and a lot can be learnt from it. However,the introduction of ADR has not been without its challenges.

\section{Lack of knowledge.}

In Lesotho, and some other countries that have introduced ADR into the court system through court-annexed mediation, the lack of knowledge and understanding of ADR by court users, has resulted in reluctance to undergo mediation. Because the court administrative staff also had limited knowledge and understanding of ADR, they were ill-equipped to provide proper guidance to court users on ADR processes, thereby exacerbating the problem. However, this is not an insurmountable problem. Extensive public awareness exercises have been used successfully in Uganda to mitigate this challenge.

\section{Resistance by legal professionals to participate in ADR processes.}

This is largely driven by lack of knowledge and understanding of ADR processes among legal professionals. There is also a perception that because ADR reduces the time for resolving disputes, it results in loss of revenue for legal practitioners. Furthermore, there is a concern that using ADR will erode the creation of jurisprudence. In every process of change, people first resist the change before embracing it. Even where lawyers have embraced ADR,their litigious nature, due to legal training, still results in an adversarial approach to ADR which is often counterproductive. 


\section{ADR is not necessarily a time saver.}

Lawyers in court annexed mediation processes often argue that ADR does not necessarily save time. It is perceived as an additional step in the litigation process because where no settlement is reached during mediation, the case is still transferred to a judge. Furthermore, in countries where parties pay for mediator's fees, it is argued that implementing compulsory mediation prior to litigation is in itself a barrier to access to justice, because it increases the cost of resolving disputes, especially where mediation is not successful. Mediation may also be dragged out for months and even years if no clear timelines are agreed upon. This is contrary to the claim that ADR is faster and therefore cheaper.

\section{ADR professionals require training}

ADR requires specific skills and cannot be conducted by persons simply because they have knowledge of the law. Lack of training can have detrimental effects on the public's attitude towards ADR. The way the ADR practitioners conduct the process, can create confidence or mistrust in the process. When this happens, it is near impossible to get the parties to have a positive attitude towards ADR. Furthermore, in many countries, the mediation profession is largely unregulated. This, together with the principle of confidentiality,means that the process is held behind closed doors and, because no other persons are permitted to attend the process without the consent of the parties, determining the mediator's competence during a process can be a challenge.

\section{ADR is only used in formal justice}

ADR is mostly introduced at the upper court level, from the high court upwards. Few attempts have been made to see how ADR can be used to enhance traditional justice practices. Nor have traditional justice practices been used to enhance ADR initiatives introduced in the formal justice system. This exclusion of traditional justice, further enforces perceptions that the system is bias and systematically favour the more powerful, elite parties and perpetuate the dominant Western culture.

\section{Conclusion}

This paper sought to argue that traditional justice mechanisms need to be incorporated into the ADR practices that are introduced in Africa. This will create familiarity and, in turn, better access to justice. This will also give recognition to existing systems of dispute resolution that are aligned to the social fabric of many African communities.

However, the paper is not suggesting that we throw out the baby with the bath water, because in many places, ADR has demonstrated its effectiveness in improving access to justice when the conditions are right. What the paper is suggesting is that caution should be exercised when trying to address issues of access to justice, not to export a model which will continue to alienate most Africans who are already alienated by the formal justice system. Instead, lessons should be drawn from studies conducted in the 
EU and Australia on the effectiveness of ADR to see how best to incorporate traditional justice systems into the formal justice system.

The paper is also not suggesting that traditional justice systems be incorporated as is. Modification of the systems is required to stem out discriminatory and oppressive cultural practises that are not in line with international human right doctrines, especially relating to women. Traditional Justice systems are rooted in patriarchal cultural norms which sometimes perpetuate discrimination against women, particularly with regards to inheritance, the status of widows, marriage, domestic abuse, rape and education of a girl child. Culturally men tend to have more power than women and this power can be abused to the detriment of women and children. One of the key reasons why South Africa's Traditional Court Bill has not been passed,the controversy surrounding the role of Traditional Leaders, who would be the custodians of justice in these courts, who are perceived by some to be an undemocratic, unaccountable and unelected institution, which upholds discriminatory cultural against women (Sithole \& Mbele, 2008).

Drawing the best from both systems to create something which is contextually and culturally relevant to Africa,bearing in mind that Africa is not homogenous, may be a good starting point to improve access to justice.

\section{References:}

1. Abunzi Act. (2016). Determining Organisation, Jurisdiction, Competence and Functioning of an Abunzi Committee. Law No.37/2016 of 08/09/2016.

2. Adonyo, H. (2012, September 24). Structure and Function of the Judiciary. A Paper presented at the Induction of New Magistrates Grade 1, Mukono, Uganda.

3. African Union Commission. (2015, October 27). Final Report of the African Union Commission of Inquiry on South Sudan. Reliefweb. Retrieved from https://reliefweb.int/ report/south-sudan/final-report-african-union-commission-inquiry-south-sudan.

4. Berinzon, M., \& Briggs, R. (2017, January 20). 60 years later, are colonial-era laws holding Africa back?. The Washington Post. Retrieved from www.washingtonpost.com/ news/monkey-cage/wp/2017/01/20/60-years-later-are-colonial-era-laws-holdingafrica-back/?utm_term $=.948 \mathrm{~d} 7 \mathrm{~b} 22737 \mathrm{~d}$.

5. Bowd, R. (2009, October 13). Access to Justice in Africa: Comparison between Sierra Leone, Tanzania and Zambia. [Policy Brief]. Pretoria: Institute for Security Studies.

6. Chereji, C., \& Wratto, K. C. (2013). West Africa: A Comparative Study of Traditional Conflict Resolution Methods in Liberia and Ghana. Conflict Studies Quarterly, 5, 3-18.

7. Chikwanha, A. (2008). Traditional Policing in Mali: The Power of Shame. Institute for Security Studies. Retrieved from https://issafrica.org/iss-today/traditional-policingin-mali-the-power-of-shame.

8. Ciftci, S., \& Howard-Wagned, D. (2012). Integrating Indigenous Justice into Alternative Dispute Resolution Practices: A Case Study of the Aboriginal Care Circle Pilot Program in Nowra. Australian Indigenous Law Review, 16(2), 81-98. 
9. Danso, K. (2016, May 2). Mending Broken Relations after Civil War: The 'Palava Hut' and the Prospects for Lasting Peace in Liberia. Accra, Ghana: Koffi Annan International Peace Keeping Training Centre.

10. Davidheiser, M. (2006). Joking for Peace. Social Organization, Tradition, and Change in Gambian Conflict Management. Cahiers d' Etudes Africaines. Retrieved from https:// etudesafricaines.revues.org/15409.

11. Davidson, B. (1992). The Black Man's Burden. Africa and the Curse of the Nation State. New York: Three Rivers Press.

12. European Parliament and Council. (2008). Directive 2008/52/EC of the European Parliament and of the Council of 21 May 2008 on certain aspects of mediation in civil and commercial matters. Official Journal of the European Union. Retrieved from http://eurlex.europa.eu/legal-content/EN/TXT/HTML/?uri=CELEX:32008L0052\&from=EN.

13. Deutsche Gesellschaft für Internationale Zusammenarbeit. (GIZ) (2013). Shimgelina Under the Shade. Merging Ethiopian Wide Counsel Mediation and Facilitative Mediation. Addis Ababa: House of Federation.

14. Ebine, S. A. (2017). The Roles of Griots in African Oral Tradition among the Manding. Lapai, Nigeria: Ibrahim Badamasi Babaginda University.

15. Elechi, 0. (2004, August 8-12). Human Rights and the African Indigenous Justice System. A paper delivered at the $18^{\text {th }}$ International Conference of International Society for the Reform of Criminal Law; Quebec, Canada.

16. Fischer, R., \& Ury, W. (1991). Getting to Yes: Negotiating Agreement Without Giving In. Boston/New York: Houghton Mifflin Company.

17. Gebre-Egziabher, K. A. (2014). Dispute resolution mechanisms among the Afar People of Ethiopia and their contribution to the Development Process. The Journal for Transdisciplinary Research in Southern Africa, 10(3), 152-164.

18. Genn, H. (2012). What Is Civil Justice For? Reform, ADR, and Access to Justice. Yale Journal of Law \& the Humanities, 24(1), 396-417.

19. Ghebrehiwet, K. (2010, June 18). Afar Customary Laws: Rich Cultural Heritage. Eritrea Ministry of Information. Retrieved from www.shabait.com/about-eritrea/history-aculture/2196-afar-customary-laws-rich-cultural-heritage.

20. Goldberg, S. F., Sander, F., Rogers, N., \& Cole, R. (2012). Dispute Resolution: Negotiation, Mediation, Arbitration and Other Processes. New York: Wolters Kluwer Law \& Business.

21. Grande, E. (1999). Alternative Dispute Resolution; Africa and the Structure of Law and Power; The horn in Context. Journal of African Law, 43(1), 63-70.

22. Haile-Selassiea, Y., Latimer, B. L., Alene, M, Deino, A. L., Gibert, L., Melillo, S. M., ...Lovejoy, C. O. (2010). An early Australopithecus afarensis Postcranium from Woranso-Mille, Ethiopia. Proceedings of the National Academy of Sciences of the United States of America, 107(27), 12121-12126.

23. Hoffman, B.G. (2000). Griots at War; Conflict, Conciliation and Caste in Mande. Bloomington and Indianapolis: Indiana University Press. 
24. Huyse, L., \& Salter, M. (2008). Traditional Justice and Reconciliation After Violent Conflict. Learning from African Experiences. Stockholm: International Institute for Democracy and Electoral Assistance.

25. Joireman, S. F. (2001). Inherited Legal Systems and Effective Rule of Law: Africa and the Colonial Legacy. Journal of Modern African Studies, 39(4), 571-596. doi:10.1017/ S0022278X01003755.

26. Kaersvang, D. (2008). Equality Courts in South Africa; Legal Access for the Poor. Journal of International Institute. Retrieved from https://quod.lib.umich.edu/j/ jii / 4750978.0015.203/--equality-courts-in-south-africa-legal-access-for-thepoor?rgn=main;view=fulltext

27. Kayigamba, J. (2012, June 15). Rwanda's Gacaca courts: A Mixed legacy. New Internationalist Magazine. Retrieved from https://newint.org/features/web-exclusive/ 2012/06/15/gacaca-courts-legacy/.

28. Kruger, R. (2011). Small Steps to Equal Dignity: The Work of the South African Equality Courts. Equal Rights Review, 7, 27-43.

29. Loschky, J. (2016, March 25). Majority in Sub-Saharan Africa Wouldn't Use Formal Courts. Gallop News. Retrieved from www.gallup.com/poll/190310/majority-subsaharan-africa-wouldn-formal-courts.aspx.

30. McManus, M., \& Silverstein, B. (2011, October).Brief History of Alternative Dispute Resolution in the USA. CADMUSA papers series of the South-East European Division of the World Academy of Art and Science (SEED-WAAS), 1(3), 100-105.

31. Mu'uz, G. (2013). The Mada'a and Mablo of the Afar: Customary System of Conflict Transformation. Paper presented at the Second Annual Research Proceeding, Wollo University, Addis Ababa. United Printing Press 2, 101-123.

32. Mutisi, M. (2011, November 1). The Abunzi Mediation in Rwanda: Opportunities for Engaging with Traditional Institutions of Conflict Resolution. Durban: ACCORD.

33. Nsanzimana, J. C. (2012, May 25). Rwanda: Abunzi and land use were a success, Research Finds. All Africa. Retrieved from http://allafrica.com/stories/201205280797.html.

34. O’Bannon, B. (2008). Speak no more of cousinage. Neoliberalism, conflict and the decline of joking relationships. Occasional Paper No. 1, African Peace and Conflict Network.

35. O’Donnell, M. (1995). Mediation within Aboriginal Communities: Issues and Challenges. In KM Hazlehurst (Ed.), Popular Justice and Community Regeneration: Pathways of Indigenous Reform (pp. 89-102). Westport: Praeger.

36. Pajabo, E. (2008). Traditional Justice Mechanisms: The Liberian Case. Stockholm: International Institute for Democracy and Electoral Assistance Publication.

37. Pankhurst, A., \& Assefa, G. (2008). Grass-Roots Justice in Ethiopia. The Contribution of Customary Dispute Resolution. Addis-Abeba: Centre français des études éthiopiennes.

38. Sithole P. \& Mbele T. (2008). Fifteen Year Review on Traditional Leadership. Cato Manor: Human Science Research Council.

39. Radar, B. \& Karimi, M.(2004). Indigenous Democracy; Traditional Conflict Resolution Mechanisms; Pokot, Turkana, Samburu and Marakwet. Nakuru: ITDG-EA. 
40. Saki O., \& Chiware, T. (2007). The Law in Zimbabwe. Globalex. Retrieved from www. nyulawglobal.org/globalex/Zimbabwe1.html.

41. Sansculotte-Greenidge, K., \& Fantaye, D. (2012). Traditional authority and Modern Hegemony: Peace-making in the Afar region of Ethiopia. In M. Mutisi and K. SansculotteGreenidge (Eds), Integrating Traditional and Modern Conflict Resolution: Experiences from selected cases in Eastern and the Horn of Africa (pp. 75-98). Africa Dialogue Monograph Series No. 2/2012. Durban, South Africa: ACCORD.

42. Sium, A. (2010). Revisiting The Black Man's Burden: Eritrea And The Curse Of The Nation-State. A MA thesis submitted for the degree of Master of Arts Graduate Department of Sociology and Equity Studies in Education, Ontario Institute for Studies in Education, University of Toronto.

43. Smith, E. (2004). Les cousinages de plaisanterie en Afrique de l'Ouest, entre particularismes et universalismes. Political Reasons, 1(13), 157-169.

44. South African Law Commission. (1999). Project 90: The Harmonisation of Common Law and Indigenous Law. Report of Conflicts of Law. Pretoria: South African Law Commission.

45. Spinks, M. (2001). Access to Justice in Sub-Saharan Africa: The Role of Tradition and Informal Justice Systems. London: Penal Reform International

46. Tesfay, Y., \& Tafere, K. (2004). Indigenous Rangeland Resources and Conflict Management by the North Afar Pastoral Groups in Ethiopia. Oslo: Drylands Coordination Group (DCG).

47. Umunadi, K. E. (2011). The Efficiency of Mediation and Negotiation Methods for Dispute Resolution in Delta State. Sacha Journal of Policy and Strategic Studies, 1(2), 64-73.

48. United Nations. (2000). Report of Committee of the Elimination of Racial Discrimination. United Nations General Assembly Fifty-fifth Session, Supplement No. 18 (A/55/18). New York: United Nations.

49. Uwazie, E. (2011, November). Alternative Dispute Resolution in Africa; Preventing Conflict and Enhancing Stability. Africa Security Brief, 16.

50. World Bank \& International Monetary Fund (2013, May 02). Global Monitoring Report 2013: Rural-Urban Dynamics and the Millennium Development Goals. Open Knowledge Repository. Retrieved from https://openknowledge.worldbank.org/handle/10 $986 / 13330$. 